\title{
Effects of Phosphorus Fertilization on Productivity of Intensively Managed Grasses Under Humid Tropical Conditions in Puerto Rico ${ }^{1}$
}

\author{
Jacinto Figarella, José Vicente-Chandler, \\ Servando Silva, and Rubén Caro-Costas ${ }^{2}$
}

\section{INTRODUCTION}

High-yielding grasses growing under humid tropical conditions respond strongly to heavy applications of nitrogen and potassium. Vicente-Chandler, et al. (12), ${ }^{3}$ (13), found that Napier grass (Pennisetum purpureum), Guinea grass ((Panicum maximum), and Pangola grass (Digitaria decumbens), growing under humid tropical conditions in Puerto Rico, responded strongly in yield and protein content to applications of up to 800 pounds of nitrogen per acre yearly. Rodriguez (7), under similar conditions, found that these grasses responded to the application of 200 pounds of nitrogen per acre yearly, the highest rate tested in this experiment. Vicente-Chandler, et al. (10), found that, with heavy nitrogen fertilization, these grasses responded strongly in yield to applications of 400 pounds or more of potassium per acre yearly.

There is little information on the effects of phosphorus fertilization on yields and composition of heavily fertilized grasses in the humid Tropics, although under these conditions grasses can withdraw as much as 300 pounds of $\mathrm{P}_{2} \mathrm{O}_{6}$ per acre yearly, as shown by Vicente-Chandler, et al. (11). Bonnet, et al. (1) found that lightly fertilized Napier and Guinea grasses, growing on Fajardo clay at Río Piedras, did not respond to phosphorus applications. Bonnet (2) has also presented data indicating that yields of lightly fertilized Napier and Guinea grasses at Río Piedras were slightly increased by phosphorus fertilization. Capó (4) found that Sudan grass responded strongly to phosphorus fertilization at Río Piedras.

This paper presents the results of experiments to determine the effects of phosphorus applications on yields and phosphorus content of otherwise well-fertilized tropical grasses growing on three typical soils of the Humid Region of Puerto Rico.

1 This paper covers work carried out cooperatively by the Soil and Water Conservation Research Division, Agricultural Research Service, USDA, and the Agricultural Experiment Station, University of Puerto Rico, Río Piedras, P.R.

2 Chemist, Project Supervisor, and Physical Science Aid, Soil and Water Conservation Research Division, Agricultural Research Service, USDA; and Cooperative Agronomist between the agencies mentioned above, respectively; stationed at the Agricultural Experiment Station, University of Puerto Rico, Río Piedras, P.R.

${ }^{3}$ Italic numbers in parentheses refer to Literature Cited pp. 241-2. 


\section{MATERIALS AND METHODS}

These experiments were conducted at Orocovis and Río Piedras, in the Humid Region of Puerto Rico. Annual rainfall averaged about 70 inches, and was fairly well distributed throughout the year, although the period from December through March was somewhat drier. Mean annual temperature was about $75^{\circ} \mathrm{F}$, with seasonal variations of about $10^{\circ} \mathrm{F}$.

EXPERIMENTS WITH NAPIER GRASS ON CATALINA

AND MÚCARA CLAY SOILS AT OROCOVIS

Both soils had been in essentially unfertilized pastures for at least 12 years before the experiment was started. Organic-matter content of the surface 6 inches varied from 3 to 4 percent. The Catalina clay had a pH of $5.0,16$ meq. of exchange capacity, 8.0 meq. of exchangeable bases per 100 $\mathrm{gm}$. of soil, and a volume-weight of 0.98 . Clay minerals of this soil are predominantly kaolinitic with a high content of free iron and aluminum oxides. The Múcara clay had a $\mathrm{pH}$ of 5.5, 25.0 meq. of exchange capacity, 18.0 meq. of exchangeable bases per $100 \mathrm{gm}$. of soil, and a volume-weight of 1.2. Clay minerals of this soil are predominantly beidellitic.

Treatments tested in these 2-year experiments were 0,150 , and 300 pounds of $\mathrm{P}_{2} \mathrm{O}_{5}$ per acre yearly, applied as 20-percent superphosphate in one annual application. A randomized block design was used with all treatments replicated four times on each soil. Plots were $10 \times 18$ feet, and were surrounded by ditches to prevent fertilizer from washing into adjoining plots.

All plots were limed to about $\mathrm{pH} 6.0$ at start of the experiments by applying 4 and 10 tons of limestone per acre to the Múcara and Catalina soils, respectively. Thereafter, 2 tons of limestone were applied per acre once a year to counteract residual acidity of the nitrogen fertilizer. All plots received 600 pounds of nitrogen, as ammonium sulfate, and 800 pounds of potassium chloride, per acre yearly in six equal applications.

The Napier grass was cut every 60 days, the forage weighed, and moisture contents determined on samples from each plot. Samples were composited by plots yearly and analyzed for phosphorus.

The surface soil in all plots was sampled at the start of the experiment. About six individual borings were taken in each plot using a Hoffer-type tube, composited, air-dried, and passed through a 20-mesh screen. Samples were analyzed for "available" phosphorus by extraction with: 1 , Sodium bicarbonate as described by Olsen (5); 2 , ammonium fluoride as described by Bray $(3)$; 3 , sodium hydroxide as described by Saunders (8); and 4 , dilute sulfuric acid as described by Truog (9), using the modifications described by Peech, et al. (6). 


\section{EXPERIMENT WITH NAPIER, GUINEA, AND PANGOLA GRASSES ON FAJARDO CLAY AT RÍO PIEDRAS}

This soil had previously been in moderately fertilized sugarcane for many years. Clay minerals are predominantly kaolinitic with a high content of free iron and aluminum oxides. The surface 6 inches of soil contained 3.2 percent of organic matter, and had 12 meq. of exchange capacity, 4 meq. of exchangeable bases per $100 \mathrm{gm}$. of soil, a $\mathrm{pH}$ of 4.8 , and a volume-weight of 1.2 .

Treatments tested in this 5-year experiment were $0,100,200$, and 400 pounds of $\mathrm{P}_{2} \mathrm{O}_{5}$, as 20-percent superphosphate, per acre yearly for the first 2 years of experimentation, or a total of $0,200,400$, and 800 pounds of $\mathrm{P}_{2} \mathrm{O}_{5}$ per acre. A randomized block design was used with all treatments replicated 4 times with each grass. Plots were $15 \times 15$ feet and were surrounded by ditches to prevent fertilizer from washing into adjoining plots.

Plots received 3 tons of limestone per acre at start of the experiment, and an additional 3 tons 2 years later. Eight hundred pounds of nitrogen, as ammonium sulfate, and 800 pounds of potassium, as potassium chloride, were applied per acre yearly in six equal applications.

The grasses were cut every 60 days, the forage weighed, and moisture contents determined on samples from each plot. Samples were composited by plots yearly and analyzed for phosphorus.

The "available phosphorus" in the surface soil of plots receiving 0 and 800 pounds of $\mathrm{P}_{2} \mathrm{O}_{5}$ per acre was determined when the experiment was terminated, using methods of sampling and analyses described previously.

\section{RESULTS}

Napier grass responded strongly to phosphorus applications on both Múcara and Catalina clay soils at Orocovis, as shown in table 1 and figure 1. Yields were increased from 18,931 to 28,344 pounds of dry forage per acre yearly on Catalina clay, and from 24,279 to 34,281 pounds on Múcara clay, by the application of 150 pounds of $\mathrm{P}_{2} \mathrm{O}_{5}$ per acre yearly. The application of 300 pounds of $\mathrm{P}_{2} \mathrm{O}_{5}$ per acre did not further increase forage yields on either soil.

The phosphorus content of Napier grass increased significantly with phosphorus applications up to 300 pounds of $\mathrm{P}_{2} \mathrm{O}_{5}$ per acre yearly on both Catalina and Múcara clay soils, as shown in table 1 and figure 1. Fifty-one pounds of $\mathrm{P}_{2} \mathrm{O}_{5}$, or 21 pounds of $\mathrm{P}$, were removed per acre yearly from the Múcara clay and 61 pounds of $\mathrm{P}_{2} \mathrm{O}_{5}$, or 26.5 pounds of $\mathrm{P}$, from the Catalina clay by Napier grass receiving no phosphorus fertilizer.

These experiments show that heavily fertilized grasses growing on typical soils of the Humid Region not previously fertilized with phosphorus may be expected to respond strongly in yield and phosphorus content to applications of this nutrient. 
Table 2 shows that neither Napier, Guinea, nor Pangola grass responded significantly in yield or phosphorus content to phosphorus fertilization on Fajardo clay at Río Piedras, even after 5 consecutive years of cropping.

TABLE 1.-Effect of phosphorus fetilization on yields and phosphorus content of Napier grass growing on 2 typical soils of the Humid Mountain Region at Orocovis

\begin{tabular}{c|c|c|c|c}
\hline \multirow{2}{*}{$\begin{array}{c}\text { P.Os applied per acre } \\
\text { yearly (pounds) }\end{array}$} & \multicolumn{2}{|c|}{ Catalina clay } & \multicolumn{2}{c}{ Múcara clay } \\
\cline { 2 - 3 } & $\begin{array}{c}\text { Dry forage } \\
\text { produced per } \\
\text { acre yearly }\end{array}$ & $\begin{array}{c}\text { P content of } \\
\text { forage on a } \\
\text { dry-weight basis }\end{array}$ & $\begin{array}{c}\text { Dry forage } \\
\text { produced per } \\
\text { acre yearly }\end{array}$ & $\begin{array}{c}\text { P content of } \\
\text { forage on a } \\
\text { dry-weight basis }\end{array}$ \\
\hline & Pounds & Percent & Pounds & Percent \\
0 & 18,931 & 0.14 & 24,279 & 0.09 \\
150 & 28,344 & .14 & 34,281 & .13 \\
300 & 32,289 & .17 & 35,098 & .17 \\
\hline L.S.D.05 & 5,880 & 0.03 & 3,360 & 0.03 \\
\hline
\end{tabular}

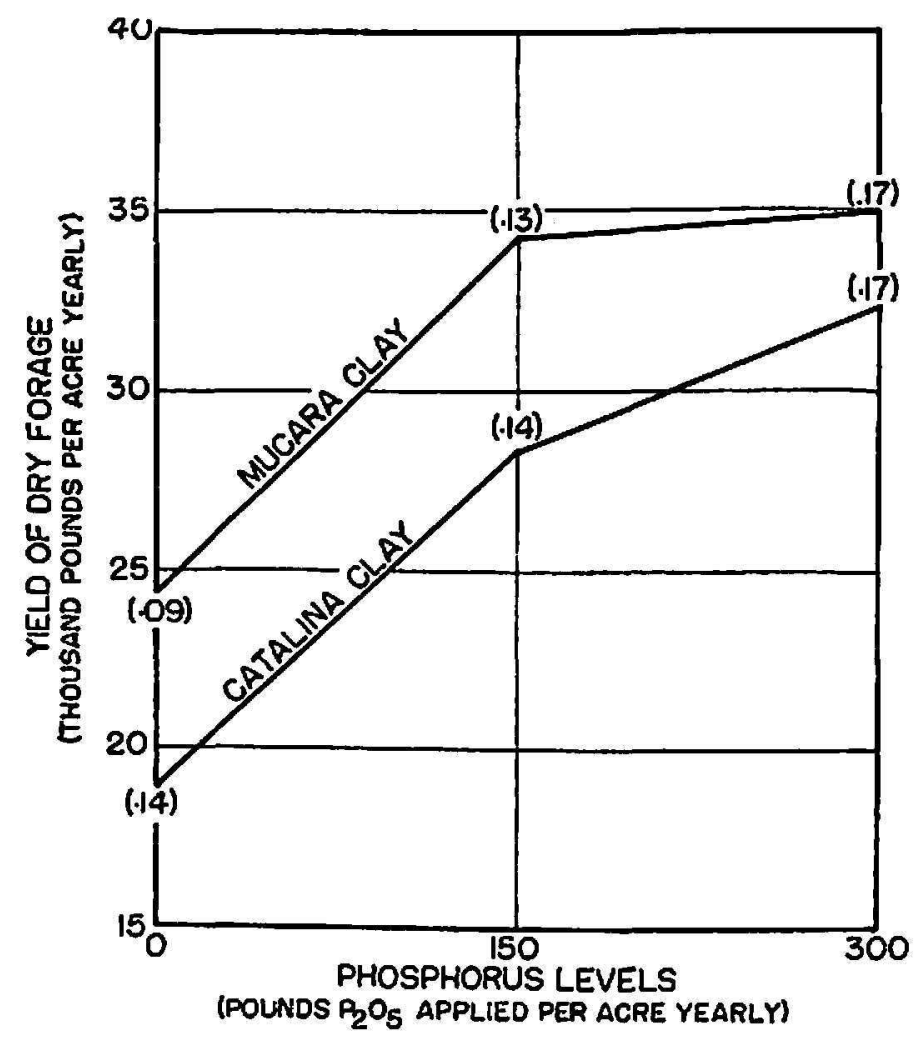

Fic. 1.-Effect of phosphorus fertilization on yields of Napier grass growing on 2 typical soils of the Humid Mountain Region of Puerto Rico. Numbers in parentheses show phosphorus content of forage on a dry-weight basis.

The grasses receiving no phosphorus removed about 92 pounds of $\mathrm{P}_{2} \mathrm{O}_{5}$, or 40 pounds of $P$, per acre yearly from the soil, or a total of 460 pounds of $\mathrm{P}_{2} \mathrm{O}_{5}$, or 200 pounds of $\mathrm{P}$, per acre during the 5 years of experimentation. These experiments show that the phosphorus content of soils formerly 
planted to sugarcane or other fertilized crops for many years may be built up to such an extent that grasses do not respond to applications of this nutrient for many years.

TABLE 2.-Effect of phosphorus fertilization on yield and phosphorus content of 3 grasses growing on Fajardo clay at Rio Piedras during the fifth year of experimentation

\begin{tabular}{|c|c|c|c|c|c|c|}
\hline \multirow{2}{*}{$\begin{array}{l}\text { Total } \mathrm{P}_{2} \mathrm{O}_{3} \\
\text { applied per } \\
\text { acre (pounds) }\end{array}$} & \multicolumn{2}{|c|}{ Napier grass } & \multicolumn{2}{|c|}{ Guinea grass } & \multicolumn{2}{|c|}{ Pangola grass ${ }^{1}$} \\
\hline & $\begin{array}{l}\text { Dry forage } \\
\text { produced per } \\
\text { acre yearly }\end{array}$ & $\begin{array}{c}\text { P content on } \\
\text { dry-weight } \\
\text { basis }\end{array}$ & $\begin{array}{l}\text { Dry forage } \\
\text { produced per } \\
\text { acre yearly }\end{array}$ & $\begin{array}{c}\text { P content on } \\
\text { dry-sveight } \\
\text { basis }\end{array}$ & $\begin{array}{l}\text { Dry forage } \\
\text { produced per } \\
\text { acre yearly }\end{array}$ & $\begin{array}{c}P \text { content on } \\
\text { dry-weight } \\
\text { basis }\end{array}$ \\
\hline & Pounds & Percent & Pounds & Percent & Pounds & Percenl \\
\hline 0 & 25,421 & 0.13 & 27,724 & 0.13 & 23,258 & 0.12 \\
\hline 200 & 27,299 & .14 & 25,552 & .12 & 26,042 & .13 \\
\hline 400 & 27,131 & .14 & 28,722 & .13 & 25,433 & .13 \\
\hline 800 & 26,840 & .14 & 32,309 & .14 & 27,144 & .14 \\
\hline
\end{tabular}

${ }^{1}$ Values are for fourth year. Pangola grass was severely attacked by insects during the fifth year and yield data obtained over this period are therefore not considered valid. No statistical significance throughout.

TABLE 3.-Available phosphorus in the 3 experimental soils as determined by various chemical methods

\begin{tabular}{|c|c|c|c|c|}
\hline \multirow{2}{*}{$\begin{array}{l}\text { Soil and depth } \\
\text { (inches) }\end{array}$} & \multicolumn{4}{|c|}{$P_{9} \mathrm{O}_{6}$ extracted with- } \\
\hline & $\begin{array}{c}\text { Ammonium } \\
\text { fluoride }\end{array}$ & Dilute acid & $\begin{array}{c}\text { Sodum } \\
\text { hydroxide }\end{array}$ & $\begin{array}{c}\text { Sodium } \\
\text { bicarbonate }\end{array}$ \\
\hline Catalina..... ${ }_{6-12}^{0-6}$ & $\begin{array}{c}L b . / A \\
<10 \\
<10\end{array}$ & $\begin{array}{c}L b . / A \\
<5 \\
<5\end{array}$ & $\begin{array}{c}L b . / A \text {. } \\
68 \\
36\end{array}$ & $\begin{array}{c}L b . / A . \\
- \\
-\end{array}$ \\
\hline $\begin{array}{r}\text { Múcara..... } \\
6-6-12\end{array}$ & $\begin{array}{l}<10 \\
<10\end{array}$ & $\begin{array}{l}<5 \\
<5\end{array}$ & $\begin{array}{l}45 \\
35\end{array}$ & - \\
\hline $\begin{array}{r}\text { Fajardo....... } \\
6-6-12\end{array}$ & $\begin{array}{l}<5 \\
<5\end{array}$ & $\begin{array}{l}<5 \\
<5\end{array}$ & $\begin{array}{l}86 \\
66\end{array}$ & $\begin{array}{l}<5 \\
<5\end{array}$ \\
\hline $\begin{array}{r}\text { Fajardo }^{2} \ldots \ldots{ }_{G-12}^{0-6} \\
\end{array}$ & $\begin{array}{l}<5 \\
<5\end{array}$ & $\begin{array}{l}<5 \\
<5\end{array}$ & $\begin{array}{l}87 \\
81\end{array}$ & $\begin{array}{l}<5 \\
<5\end{array}$ \\
\hline
\end{tabular}

${ }^{1} 800 \mathrm{lb}$. of $\mathrm{P}_{2} \mathrm{O}_{5}$ applied per acre.

None of the methods for determining "available" soil phosphorus gave satisfactory results (table 3). Extraction with sodium bicarbonate, dilute sulfuric acid, or ammonium fluoride failed to remove appreciable quantities of phosphorus from any of the soils, including the Fajardo clay which 
supplied a total of 460 pounds per acre of $\mathrm{P}_{2} \mathrm{O}_{5}$ to the grasses over a 5-year period. Considerable phosphorus was removed from all the soils by extraction with sodium hydroxide, and this method gave some evidence of distinguishing between the low-phosphorus Catalina and Múcara soils and the high-phosphorus Fajardo. None of the methods tested detected the higher phosphorus content of the Fajardo clay receiving 800 pounds of $\mathrm{P}_{2} \mathrm{O}_{5}$ per acre.

\section{SUMMARY}

The effects of phosphorus applications on yields and phosphorus content of otherwise well-fertilized tropical grasses growing on three typical soils of the Humid Region of Puerto Rico were determined.

Napier grass responded strongly in yield to applications of 150 pounds of $\mathrm{P}_{2} \mathrm{O}_{5}$ per acre yearly on both Múcara and Catalina clay soils at Orocovis. The phosphorus content of the forage increased with applications of up to 300 pounds of $\mathrm{P}_{2} \mathrm{O}_{5}$ per acre yearly on both soils.

On the other hand, Napier, Guinea, and Pangola grasses, growing on a Fajardo clay formerly in moderately fertilized sugarcane for many years, did not respond in yield or phosphorus content to applications of phosphorus over a 5-year period.

Various methods of determining "available" soil phosphorus did not give satisfactory results with these soils.

\section{RESUMEN}

Se determinaron los efectos de las aplicaciones de fósforo sobre el rendimiento y contenido de fósforo de varias yerbas tropicales en suelos típicos de la región húmeda de Puerto Rico.

El rendimiento de la yerba Napier en suelos Múcara y Catalina arcilloso aumentó marcadamente cuando se le aplicó fósforo, a razón de 150 libras de $\mathrm{P}_{2} \mathrm{O}_{5}$ por cuerda, anualmente. También aumentó el contenido de fósforo en el forraje de esta yerba con las aplicaciones de este nutrimento hasta 300 libras por cuerda, anualmente.

Por otro lado, las yerbas Napier, Guinea y Pangola en un suelo Fajardo arcilloso sembrado anteriormente de caña, abonado moderadamente durante muchos años, no respondieron a las aplicaciones de fósforo.

Cuando se usaron varios métodos para determinar el fósforo disponible en estos suelos no se obtuvieron resultados satisfactorios.

\section{LITERATURE CITED}

1. Bonnet, J. A., and Riera, A. R., Tracing the mineral from the soil to the plant to the animal blood, J. Agr. Univ. P.R. 33 (2) 57-73, 1950.

2. Bonnet, J. A., Chemical Data of Puerto Rico Soils, Agr. Expt. Sta. Univ. P.R. B. 1, 1941. 
3. Bray, R. H., and Kutz, L. T., Determination of total organic and available forms of phosphorus in soils, Soil Sci. 69 39-45, 1945.

4. Capo, B. G., A modification of Mitscherlichs method for the determination of the nutrient contents of a soil, J. Agr. Univ. P.R. 22 (2) 137-69, 1938.

5. Olsen, S. R., Cole, C. V., Watanabe, F. S., and Dean, L. A., Estimation of Available Phosphorus by Extraction with Sodium Bicarbonate, Circular 939, USDA, 1954.

6. Peech, M., Dean, L. A., and Reed, F., Methods of Soil Analysis for Soil Fertility Investigations, Circular 757, USDA, 1947.

7. Rodríguez, J. P., Effect of nitrogen applications on the yields and composition of forage crops, J. Agr. Univ. P.R. 32 (3) 98-117, 1949.

8. Saunders, D. H., Determination of available phosphorus in tropical soils by extraction with sodium hydroxide, Soil Sci. 82 (6) 457, 1956.

9. Truog, E., The determination of the readily available phosphorus of soils, Amer. Soc. Agron. J. 22 874-82, 1930.

10. Vicente-Chandler, J., Pearson, R. W., Abruña, F., and Silva, S., Potassium fertilization of intensively managed grasses under humid tropical conditions, Agron. $J .54$ 450-3, 1962.

11. Vicente-Chandler, J., Silva, S., and Figarella, J., The effect of nitrogen fertilization and frequency of cutting on the yield and composition of three tropical grasses, Agron. J. 51 (4) 202-6, 1959.

12. - - - - and - , The effect of nitrogen fertilization and frequency of cutting on the yield and composition of : I, Napier Grass, II, Guinea Grass, and III, Para Grass, J. Agr. Univ. P.R. 43 (4) 215-48, 1959.

13.,-- , and - , Effects of nitrogen fertilization and frequency of cutting on the yield and composition of Pangola grass in Puerto Rico, J. Agr. Univ. P.R. 45 (1) 37-45, 1961. 